l'homogénéité de la communauté universitaire volerait en éclats au moment où d'autres groupes auraient à payer le prix des avantages accrus consentis aux professeurs e.g. à payer des frais de scolarité plus élevés ou des taxes plus lourdes.

D'autre part, le processus fera ressortir les conflits entre différents groupes, par exemple entre les professeurs permanents et non-permanents, les facultés professionnelles et non professionnelles. Mais, note l'auteur avec pertinence, l'ensemble du corps professoral doit savoir reconnaître que la force de négociation de l'ensemble repose sur celle des groupes les plus forts. Si tel est le cas, les divergences d'intérêt se résorberont d'elles-mêmes.

Gilbert Levine, "Collective Bargaining in University Faculties Pros and Cons", pp. 727-35.

Dans son court texte, Gilbert Levine lance un cri du coeur: La syndicalisation devrait amener les professeurs d'université à s'unir aux travailleurs "ordinaires". Si ce résultat était atteint, un bénéfice social (ou externe) s'ajouterait aux avantages directs que leur apporterait la négociation collective.

Cependant, bien que je partage ce point de vue, je douterais fort que le pont soit jeté entre les syndicats d'enseignants universitaires et le mouvement syndical traditionnel. En effet, si l'on considère que la CEQ est elle même une centrale largement dominée par une catégorie professionnelle, il ne reste que le syndicat des professeurs de l'UQUAM qui soit affilié à la CSN. Et l'UQUAM à de nombreux égards, constitue un cas particulier.

\title{
EN GUISE DE CONCLUSION
}

Après lecture de ces cinq essais, il serait difficile d'en déterminer le commun dénominateur. Chacun doit plutôt être considéré comme explorant une facette d'une question complexe. Dans l'ensemble, ils constituent toutefois un excellent point de départ et une source abondante de réflexion pour qui voudrait examiner sérieusement pour la première fois les implications de la syndicalisation universitaire.

Une mise en garde toutefois: compte tenu des événements récents sur le front universitaire, je pense ici au Québec surtout, il me semble que ces textes vieilliront rapidement.

Claude D'Aoust

Université de Montréal

Garnet McDiarmid, ed., From Quantitative to Qualitative Change in Ontario Education, A Festschrift for R. W. B. Jackson. Toronto: The Ontario Institute for Studies in Education, Toronto, 1976. $190 \mathrm{pp}$.

In his several roles as researcher, statistician, cabinet advisor and, for the decade 1965-75, Director of the Ontario Institute for Studies in Education, R.W.B. Jackson stimulated and nurtured the expansion and improvement of education in Ontario. In the main he worked quietly behind the seats of power, but his influential address, "The Problem of Numbers in University Enrolment," to the Canadian Education Association in 1963 was, as John Holland points out, "a nearly irrefutable brief for a mobilization of political and financial resources 
to accommodate predictable social, demographic, and economic realities." It is then entirely fitting that eight of his OISE colleagues should honour him with a series of papers on the broad theme of educational change. The title, by the way, does not reflect the content, and one can only assume it was imposed on the book after the articles were written. None of the authors consciously addresses himself to the question of "qualitative change," probably because the term itself is too slippery to handle with any comfort.

The primary focus of the collection rests on the sixties and seventies, a period so marked by change, and at least to those who have toiled at OISE over the past decade, a period that seems so long Clive Beck refers to it as an era. It was a time of dramatic growth and diversification, particularly in post-secondary education, but behind the galloping statistics lies the question of equality of opportunity and access. Edward Harvey examines this issue and argues that financial support is only one of the measures to be considered in determining equality of access. If genuine equality is to be achieved students should be selected in the first instance on the basis of proportional representation by sex, class (as measured by parents' education), and ethnicity. Those who achieve the best academic results in each of the groups selected by the initial criteria would be chosen for admission; and finally, access should be equalized by a plan of loans, bursaries and other forms of assistance. Such a system, Harvey maintains, would provide a proportional representation of students based on the measurement of certain relevant characteristics of our society and would allow for greater equality of access than present admission policies which are biased toward the children of the middle and upper classes. A scheme that would arbitrarily establish the mix of university students may, on its face, create greater equality of access, but is it possible to speak of equality if a middle-class student with superior academic qualification is refused admission in order to make way for a less-qualified member of a minority group?

The expansion of graduate study in education in Ontario is ably revealed by George Flower who also enthusiastically affirms the original design of OISE in uniting graduate studies, research, and field development within one institute. Clearly, the need for programs of graduate work has been demonstrated: in OISE's first decade enrolment in the regular academic year increased five-fold (from 441 to 2203), and in the summer session it tripled (from 430 to 1310 ). It is hardly likely, however, that such growth will continue; the faculties of education in other universities now have well-established graduate programs, the funding of graduate studies in all fields is under review by the Ministry of Colleges and Universities, and the pace of mobility within the education profession has slowed as the demand for, say, school administrators is well below that of a decade ago.

Now that the exuberance of the sixties for growth and expansion has spent itself, educators are, willingly or not, increasingly concerned with goals and priorities. Following a brief but discerning discussion of the futility that has marked many recent attempts to define and identify educational goals, William Alexander probes the role of the policy researcher. In contrast to the "goal-like" sentences of the administrative official which are usually vague and ambiguous, rich in connotative terms but short on denotation, the policy researcher's goals are, or should be, explicit, concrete and measurable. A markedly different approach to goals is found in Clive Beck's paper. Here the basis for determining the goals for education lies in ultimate or basic human values which are identified as "survival, happiness, fulfillment, friendship, the welfare of others, respect from others, freedom and so on ...." Prof. Beck proposes a major shift of emphasis and a radical reassessment of both 
the goals and the tasks of educational research and development, away from a preoccupation with efficiency, technology, administration and measurement, and towards that kind of educational activity that is concerned with the acquisition of "outlooks, skills, attitudes, emotions, and behaviour patterns that will enable individuals and groups to attain ultimate life goals ...." The teaching and learning strategies appropriate for this kind of educational activity are to be found, of course, in "value education," the major tenets of which are offered in a brief but remarkably cogent summary .

Any attempt to lead young people to a consideration of basic values must recognize both relativity and change. This Jack Quarter does in examining the shifting ideologies of youth in Canada. His evidence, taken largely from studies undertaken in the sixties, does not add significantly to what is now a familiar litany: a segment of the youth population has joined the "great refusal" by not adopting conventional roles and values and by showing only limited enthusiasm for the achievement ethic. The problem one has with evidence of this kind is whether or not it is representative, and whether the data are ephemeral. Was the counter culture a unique phenomenon of the sixties, or is the alienation of youth from the values and demands of an industrial and capitalist society a wide-spread, deepseated and continuing malaise? The evidence provided here is not conclusive.

A preoccupation with youth, and more particularly with the formal elementary and secondary school system, is little short of anathema to Alan Thomas. He believes that the theory of a direct relationship between the education of the young and economic development is just as outdated as the North American commitment to the elementary/secondary school as a major, if not the chief, agent of socialization. A child-centred system must give way to an increasing concern for adults with the creation of a "learning society" in which learning needs and educational opportunity are matched at all stages of growth and maturation.

Garnet McDiarmid's chapter, "Trends in Society, Trends in Curriculum," is I regret to report both rambling and superficial. There is, of course, a certain fascination in a onceover-lightly treatment of major educational issues and developments in the last several decades, but there is little for the mind simply in the delineation of trends.

John Holland's essay "Education, Public Policy and Personal Choice," is I think the best piece in the book because it not only describes and interprets recent educational development but places that development in an historical frame. He also writes with a lighter touch and less academic intensity than his colleagues:

Academic institutions are very much like love children. They exist in one period of time as the products of what has turned out to have been an overly enthusiastic relationship in another period of time. They usually grow up in a climate quite different from the one in which they were conceived. In the early 1960's, Ontario became incautiously enamoured of the academic community. Her ardour has cooled, but she now has OISE, indeed a sizeable litter of new institutions, to care for or neglect as she can and will. There may be some reconciliations between policy makers and the academic community of Ontario in the future, but they shouldn't be expected to last, and this institution like many another will have to find affection where it can, and a place in the sun if it can.

The historical perspective is provided in a section in which he analyzes the notions of progress held by nineteenth century political philosophers and classical economists and 
documents the main features of public policy related to education. Holland's view is that the "advocacy of public and compulsory education, though it contradicts the principles and policy of individualism, was a concomitant development of the intellectual foundations of individualism and capitalism." With a belief in progress went the related conviction that an increasing quantity of public education was a policy imperative. To Holland, the idea of progress when it is taken to mean an improved standard of living for an increasing proportion of an expanding population is, as a long-run policy objective, nothing less than absurd. If, as he asserts, we are now faced with the virtual collapse of a century-old consensus on the implications of the idea of progress, the challenge of accommodating to a very different economic and political environment faces all educational institutions, and not least OISE.

This collection of essays is then not only a tribute to Dr. Jackson and a welcome recognition of his contribution to public education in Ontario, but at the same time a series of storm signals, some brighter than others, of heavy weather ahead and of the need to chart a new course and develop new imperatives.

\author{
Ernest Stabler \\ University of Western Ontario
}

Objectifs généraux de l'enseignement supérieur et grandes orientations des établissements. Cahier IV: Perspective 1976 des orientations de l'enseignement supérieur. Ste-Foy, Québec: Conseil des universités, 1976. 305 pp.

Après la publication de ses trois premiers cahiers en 1972-1973 - le premier résumant les caractéristiques de l'évolution de l'enseignement supérieur au Québec au cours des dix dernières années, le second proposant des objectifs au développement de cet enseignement supérieur et le troisième faisant le bilan des orientations des établissements - le Conseil des universités vient de publier un quatrième cahier qui se veut un rapport sur l'évolution des efforts de planification dans l'enseignement supérieur au Québec. Ce cahier se situe dans un cadre de réévaluation continue des recommandations passées du Conseil. Le plan et les objectifs du rapport en découlent: réflexion sur les rôles et responsabilités des différents partenaires, bilan de l'évolution récente de l'ensemble du réseau, et évaluation de l'effort de rationalisation de chaque établissement.

Face aux tendances centralisatrices de l'Etat québécois (Comité conjoint des programmes, opérations sectorielles, programme FCAC, formule de financement) le Conseil juge bon de réaffirmer son attachement à une planification de type incitatif, chaque université devant s'ajuster librement et selon sa dynamique, au plan général. Cette approche, unanimement recommandée par les théoriciens mais souvent délaissée par les praticiens, ne peut réussir que si les rôles et les responsabilités de chacun des agents ont été délimités en vue d'assurer l'efficacité et le rendement maximum du système. Ceci est particulièrement vrai pour les établissements qui se sont souvent interrogés sur la place qui leur serait réservée dans le processus de planification ainsi que sur les rapports avec les autres institutions perçues plus comme des concurrentes que comme des partenaires. Encore là s'agit-il plus d'instaurer un climat de souplesse et de confiance mutuelle plutôt que d'officialiser les rôles! 